\title{
MODE MANAGEMENT OF THE ORGANIC MATTER IN AGROTSENOSIS OF UKRAINIAN POLISSIA
}

\section{Kravchuk M. M., Kropyvnytskyi R. B.}

\section{INTRODUCTION}

The soil cover of Polissia includes soils, mainly light on particle size distribution, with low resistance to anthropogenic pressure and low ability to self-control. For such conditions development and deployment of agrotechnologies which promote activization of soddy process of soil formation at low expenses of energy and resources of technogenic origin has priority value. Their effective introduction requires a research of influence of basic elements of agrotechnology biologization of on an abiotic component of an agroecosystem in concrete soil climatic conditions.

In a virgin state the soil is, as a rule, characterized by high stability, ability to self-control and maintenance of the main properties according to dynamics of soil formation factors during the time. On the other hand, inclusion of a soil cover in intensive economic use, especially with application of traditional plowing, is followed by the accelerated decomposition of organic matter of the soil and emission of carbon dioxide in the atmosphere ${ }^{1}$. As a result, the majority of soils lost $20-50 \%$ $\mathrm{C}$, and concentration of $\mathrm{CO}_{2}$ in the atmosphere increased by $10-12 \%$ in comparison with preindustrial time $\mathrm{i}^{2,3}$.

For light soils of Polissia a problem of dehumification and unproductive withdrawal of carbon from economic circulation is especially relevant. The average content of a humus in light soils of podzolic type in Polissia does not exceed $1.0 \%$ that excludes self-control of an ecosystem ${ }^{4}$.

${ }^{1}$ Кравчук М.М., Мартенюк Г.М., Кравчук Т.В. Вплив агротехнологій на запаси детриту в ясно-сірих лісових грунтах Полісся. Новітні системи землеробства та иляхи підвищення еколого-біологічної ефективності використання земель в сучасному агрокомплексі : матеріали Міжнар. науковопракт. конф. Дніпро : ДДАЕУ, 2017. С. 108-110.

${ }^{2}$ Ганжара Н.Ф., Борисов Б.А. Гумусообразование и агрономическая оценка органического вещества почв. Москва : Агроконсалт, 1997. 852 с.

${ }^{3}$ Ковда В.А. Биохимия почвенного покрова. Москва : Наука, 1985. 263 с.

${ }^{4}$ Стрельченко В.П., Кравчук М.М. Вплив грунтозахисних агротехнологій на динаміку органічної речовини дерново-підзолистих грунтів Полісся. Науковий вісник НАУ. 2005. Вип. 81. С. 29-34. 
Therefore, production activity in an agroecosystem has to be concentrated on preservation of soil fund from strengthening of degradative processes which already became "a showcase" of the present.

There is a need of development and broad application of a package of measures for prevention of destructive processes for a landscape which efficiency can be realized only in a system of soil-protective agriculture where the way of tillage and use of internal reserves of the soil is defining. Use of soil-protective agrotechnologies on the basis of minimizing tillage of the soil, the maximum involvement in the soil of organic matter by saturation of a crop rotation bean and intermediate crops, introduction of manure, green fertilizers, collateral products, etc. to promote optimization of the mode of organic matter in the soil. It will allow to slow down increasing of $\mathrm{CO}_{2}$ concentration in the atmosphere and to increase the general level of environmental safety of an agroecosystem.

The problem of optimization of the mode of organic matter at cultivation of a row crops as plowing significantly influences reduction of stocks of the detritus which acts as a near reserve of food of plants and is raw materials in process of humus creation is particularly acute. Therefore, the question of improvement of the agrotechnologies promoting accumulation of fraction of the detritus without decrease in productivity of cultures is particularly acute. Detritus is a valuable compound of labile organic part of the soil as is a near reserve for soil food of plants and a source of formation of actually humic substances ${ }^{5}$.

Regulation of the mode of an organic part of the soil is crucial for realization of ecological functions of the soil and optimization of its main properties and the modes, creates prerequisites for increase in productivity and stability of agrotsenosis. It is established that the optimum content of carbon of a labile organic part in an arable layer of the soddy podzolic soil for grain crops is $0.2-0.4 \%$ of mass of the soil $(6-12 \mathrm{t} / \text { hectare })^{6,7}$.

According to researchers, such maintenance of labile organic chemistry (at a ratio $\mathrm{C}: \mathrm{N}<25$ ) provides $50 \%$ of need for nitrogen for formation of a grain yield of cultures. Other $50 \%$ have to be provided at the expense of the system of fertilizer of cultures. Content less than $0.1 \%$ ( $3 \mathrm{t} / \mathrm{hectare})$ by

5 Кравчук М.М., Кропивницький Р.Б., Кравчук Т.В. Негуміфікована органічна речовина грунту як фактор регулювання твердості світло-сірих лісових грунтів Полісся. Вісник ЖНАЕУ. 2015. № 2 (50), т. 1. С. 10-15.

${ }^{6}$ Ганжара Н.Ф., Борисов Б.А. Гумусообразование и агрономическая оценка органического вещества почв. Москва : Агроконсалт, 1997. 852 с.

${ }^{7}$ Борисов Б.А. Легкоразлагаемое органическое вещество целинных и пахотных почв зонального ряда европейской части России : автореф. дис. ... д. биол. н. : 03.00.27. «Почвоведение»; МСХА им. К.А. Тимирязева. Москва, 2008. 40 с. 
M.F. Ganzhara is recognized as critical ${ }^{8}$. The deficiency of labile organic chemistry defines deterioration in the nutritious mode and structural condition of the soil. Therefore, rational land use is impossible without maintenance in the soil of a certain maintenance of organic weight, is easily mineralized ${ }^{9}$. As researchers note, stocks of a nonhumification organic part of the soil in agrotsenosis are defined, first of all, by the nature of use of an arable land, but not genetic type of the soil.

\section{Influence of crop technologies cultivation on the maintenance of a humus}

One of research problems was supposed to follow the influence of agrotechnologies on dynamics of maintenance of a humus in the soddy podzolic gleyless argillo-arenaceous soil on a moraine. Results of longterm researches of laboratory of agroecology of Institute of agriculture of Polissia NAAS. Researches were conducted in a typical field crop rotation with such alternation of cultures: potatoes; oats + clover (mix); clover; winter wheat; fiber flax; corn (silage); winter wheat; a lupine $(\mathrm{f} / \mathrm{m})$ (vika+oat in the II rotation); winter rye. According to the scheme of experience such systems of tillage were studied:

1. Traditional technology on the basis of plowing on depth of 18-20 cm (P 18-20).

2. Soil-protective technology on the basis of moldboardless tillage on 18-20 cm (ML 18-20).

3. Soil-protective different depths: moldboardless tillage under winter grain crops on 10-12 cm, under summer crops on 18-20 cm, under potatoes and corn on $28-30 \mathrm{~cm}$ (in the II rotation in all summer crops on $18-20 \mathrm{~cm})\left(\mathrm{MD} \frac{10-12}{18-20}\right)$.

These systems of tillage were studied with use of three levels of fertilizer: 1) without fertilizers; 2) one norm; 3) one and a half norms (tab. 1).

In area the crop rotation was developed by three fields. Frequency of experience 4 times. Area of a sowing campaign of the site of 180 sq.m, accounted - 100 sq.m. Also studying of a role of gley process in a dehumification of an arable layer of the soddy podzolic soil was supposed that was realized by laying of the corresponding model experience. Researches on accumulation of the detritus and studying of

${ }^{8}$ Ганжара Н.Ф. Почвоведение. Москва : Агроконсалт, 2001. 392 с.

${ }^{9}$ Мукина Л.Р., Шпедт А.А. Содержание и запасы лабильного органического вещества в почвах агроценозов и залежей. Вестник Красноярского ГАУ. 2008. № 4. С. 37-41. 
its separate properties under the influence of various systems of fertilizer were in addition conducted on the basis of a hospital which is located in the Chernyakhiv district of the Zhytomyr region on the research field of the Polissia national university. The researched area was placed on the light gray forest sandy soil on the less loam spread by flyuvic-glyacial deposits. Studying of the specified questions was carried out on soilprotective technology of tillage of the soil in a crop rotation with such alternation of cultures: Field Peas+oats (grain); winter rye; potatoes. Frequency of experience - three times. Area of a sowing campaign of the site of 58 sq.m, accounted -25 sq.m.

Table 1

Norms of application of fertilizers on crop rotation hectare, Research Farm "GROZINSKE"

\begin{tabular}{|c|c|c|c|c|c|c|c|c|c|}
\hline \multirow{3}{*}{ Rotation } & \multirow{3}{*}{$\begin{array}{l}\text { Without } \\
\text { fertilizer } \\
\mathrm{s}\end{array}$} & \multicolumn{4}{|c|}{ One norm } & \multicolumn{4}{|c|}{ One and a half norms } \\
\hline & & \multirow{2}{*}{$\begin{array}{l}\text { manure, } \\
\text { t/hectare }\end{array}$} & \multicolumn{3}{|c|}{ kg/hectare } & \multirow{2}{*}{$\begin{array}{l}\text { manure, } \\
\text { t/hectare }\end{array}$} & \multicolumn{3}{|c|}{ kg/hectare } \\
\hline & & & $N$ & $P$ & $K$ & & $N$ & $\boldsymbol{P}$ & $K$ \\
\hline I & 0 & 13.3 & 47 & 56 & 67 & 17.8 & 65 & 77 & 93 \\
\hline II & 0 & 8.9 & 30 & 35 & 43 & 13.3 & 46 & 51 & 62 \\
\hline Average & 0 & 11.1 & 39 & 46 & 55 & 16.0 & 55 & 64 & 78 \\
\hline
\end{tabular}

In soil samples were defined: a humus across Tyurin (GOST 2621391), $\mathrm{pH}$ electrometric (GOST 26483-85), hydrolytic acidity on Kappen in modifications of TsINAO (GOST 26212-91), mobile phosphorus and exchange potassium behind Kirsanovy (GOST 26207-91). From physical and water physical properties decided particle size distribution by a pipettes method on preparation of the soil with Kachinsky, the volume mass of the soil by a boring method across Kachinsky, the maximum hygroscopic humidity beyond Nikolaev.

For assessment of the impact of systems of tillage and fertilizer on dynamics of nonhumification organic matter on soddy podzolic and light gray forest soils. Layer-by-layer sampling of the soil on depths of $0-10$ and 10-20 cm were carried out by a drill of a special design (V. Strelchenko, 1993). The volume of a working sample is $196 \mathrm{~cm}^{3}$, the number of selections made 25 on each option of experience. The biological activity of the soil was defined by method of appliques in fivefold frequency by horizontal laying of a linen cloth and exhibiting of straw, the green manure and the detritus in a layer of $0-10 \mathrm{~cm}$.

For agroecological assessment of soil-protective technologies of cultivation of crops balance calculations of stocks of a humus for the 
Y. Chesnyak method and power characteristic through the corresponding coefficients according to Yu.A. Tarariko in co-authorship were used (2001).

The course of processes of soil formation in an ecosystem and also its productivity is connected with features of weather conditions. According to Korosten of a meteorological station average long-term an amount of precipitation makes $573 \mathrm{~mm}$, hydrothermal coefficient $(\mathrm{IV}-\mathrm{VI})=1.49$, the hydrothermal coefficient $(\mathrm{VII}-\mathrm{IX})=1.51$. The analysis of weather conditions showed that during functioning of stationary experience of RF "GROZINSKE" considerable deviations from mean annual levels both on the moistening mode, and on temperature were recorded that could not but affect productivity of cultures, the soil modes and transformation of organic matter.

It is difficult to overestimate a role of a humus, and preservation of its stocks is the key to economic and ecological stability. However, the trend of loss of this resource is characteristic of modern agriculture. Acceleration of processes of a dehumification of Polissia soils by researchers' contacts violation of balance in an agroecosystem because of imbalance of the existing structure of land grounds and acreage, low levels of intake of organic substrate and application of not enough systems of tillage of the soil and fertilizer justified from ecological positions. In this regard, ecologically reasonable management of replenishment of stocks of a humus and losses in specific conditions is extremely important.

In agrotsenosis an important source of organic matter is the vegetable remains which volumes of receipt are defined by qualitative structure of a crop rotation and productivity of cultures. Calculation results of balance of a humus testify to a powerful contribution of long-term herbs to article of receipt, proves their high agronomical and ecological importance. So, in the second rotation their share on not fertilized backgrounds made $36.3-37.5 \%$ of the general intake of humificated organic matter, on fertilized - 29.8-31.5\%. In the first rotation the specific weight of a clover was slightly less (19.3-22.7\%) and conceded by efficiency to a lupine (24.1-25.8\%).

Researches showed that in the second rotation of a crop rotation without fertilizers there was a decline in production of a crop rotation for 14.5-18.6\% whereas on fertilized at one norm of fertilizer falling made $7.5-9.0 \%$, and at 1.5 norms $-2.4-3.5 \%$ that significantly affected the level of intake of organic material to the soil (tab. 2). 
Table 2

Crop rotation productivity depending on the systems of tillage and levels of fertilizer, $t$ /hectare of grain units (RF “GROZINSKE")

\begin{tabular}{|c|c|c|c|c|}
\hline \multirow{2}{*}{ Rotation } & $\begin{array}{c}\text { the Level } \\
\text { of fertilizer }\end{array}$ & P 18-20 & ML 18-20 & MD $\frac{10-12}{18-20}$ \\
\hline \multirow{4}{*}{ I } & Without fertilizers & 29.2 & 32.7 & 30.6 \\
\cline { 2 - 5 } & One norm & 38.3 & 41.0 & 40.0 \\
\cline { 2 - 5 } & $\begin{array}{c}\text { One and a half } \\
\text { norms }\end{array}$ & 38.9 & 41.7 & 40.5 \\
\hline \multirow{3}{*}{ II } & Without fertilizers & 23.8 & 26.9 & 26.2 \\
\cline { 2 - 5 } & One norm & 34.9 & 38.0 & 37.0 \\
\cline { 2 - 5 } & $\begin{array}{c}\text { One and a half } \\
\text { norms }\end{array}$ & 37.5 & 40.3 & 39.5 \\
\hline \multirow{3}{*}{ Average } & Without fertilizers & 26.5 & 29.8 & 28.4 \\
\cline { 2 - 5 } & One norm & 36.6 & 39.5 & 38.5 \\
\cline { 2 - 5 } & $\begin{array}{c}\text { One and a half } \\
\text { norms }\end{array}$ & 38.2 & 41.0 & 40.0 \\
\hline
\end{tabular}

At the same time, advantage of minimization of tillage which was maximum on option with moldboardless on $18-20 \mathrm{~cm}$ was obvious. So, on average for two rotation of application of such system of tillage against the background of without fertilizers promoted growth of efficiency of a crop rotation by $12.6 \%$ in comparison with option where traditional plowing was carried out. And still more effective factor in increase in productive function in an agroecosystem is fertilizers. The high efficiency of two levels of a system of fertilizer by tillage options significantly did not differ and was $32.6-44.4 \%$.

Does not raise doubts that dynamics of productivity of a crop rotation under the influence of the systems of tillage and fertilizer affected also the maintenance of a humus. So, in the conditions of this experience between productivity (Psiv, t/hectare of grain units) and humus stocks $(G, \mathrm{t} /$ hectare $)$ exists the linear dependence ${ }^{11}$ :

$$
P \text { siv }=0,92363 G-3,445(r=0,848)
$$

It is established that prolonged use of various systems of tillage and fertilizer in the first rotation of a crop rotation significantly influenced

10 Кравчук М.М. Оптимізація режиму органічної речовини у легких за гранулометричним складом грунтах Полісся : автореф. дис. ... канд. с.-г. наук : 06.01.03 «Агрогрунтознавство і агрофізика». Київ, 2005. 21 с.

11 Кравчук М.М. Оптимізація режиму органічної речовини у легких за гранулометричним складом грунтах Полісся : автореф. дис. ... канд. с.-г. наук : 06.01.03 «Агрогрунтознавство і агрофізика». Київ, 2005. 21 с. 
increase in maintenance of a humus in the soil except for plowing option against the background of without fertilizers (tab. 3). Decrease in efficiency of a crop rotation and correction of a system of fertilizer of cultures in the second rotation caused corresponding change of levels of accumulation of a humus. However, advantage of soil-protective tillage remained also in the second rotation.

The analysis of dynamics of accumulation of a humus in an arable layer of earth showed that the factor of fertilizer (fig. 1) had the greatest influence on these processes. So, against the background of moldboard tillage (plow) for the first rotation of a crop rotation of rather starting position for laying of experience (33.4 t/hectare) application of an organo-mineral system of fertilizer provided accumulation of stocks of a humus, in particular, on unary norms this gain was $22.9 \%$, and when using one and a half norms it grew to $30.5 \%$. Options of soil-protective tillage are characterized by more intensive accumulation of humus that is shown also on sites where fertilizers were not applied. The general gain of a humus at moldboardless tillage on 18-20 cm depending on levels of fertilizer increased by $31.4-54.8 \%$, and against the background of soilprotective different depths tillage it made according to $21.4-45.7 \%$.

Comparison of the actual stocks of a humus with settlement, received on the basis of determination of balance of a humus in a crop rotation by G.Y. Chesnyak's method, shows that at the condition of application of plowing this method works and allows to receive comparable results (fig. 2). At the same time, on options of technologies the fir-tree of tillage observes significant lag of rated sizes from actual. It, according to us, is connected with creation of more favorable conditions for accumulation of humus at prolonged use of soil-protective tillage.

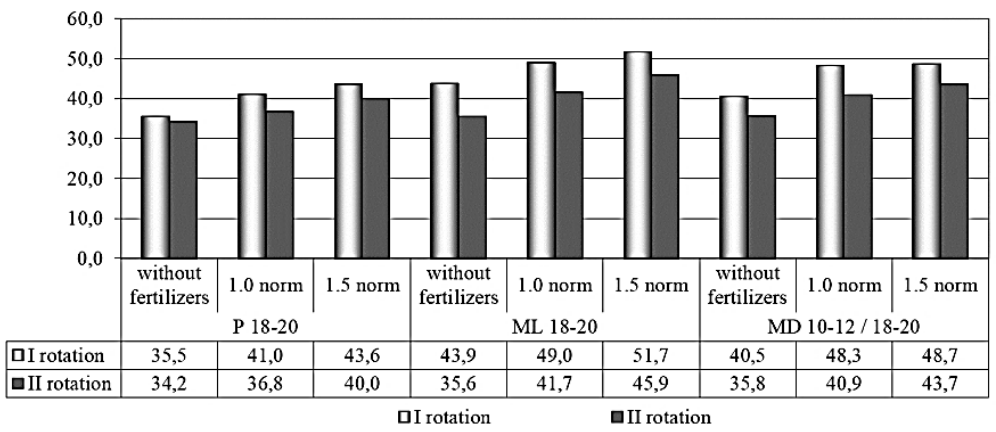

Fig. 1. Change of stocks of a humus under the influence of various systems of tillage of the soil and fertilizer, $t /$ hectare 
Influence of systems of tillage of the soil and fertilizers on the maintenance of a humus $(n=12), \%^{12}$

\begin{tabular}{|c|c|c|c|c|}
\hline \multirow[b]{2}{*}{ Option } & \multirow[b]{2}{*}{ Depth, cm } & \multicolumn{3}{|c|}{ Norm of fertilizers } \\
\hline & & $\begin{array}{c}\text { without } \\
\text { fertilizers }\end{array}$ & one & $\begin{array}{c}\text { one and a } \\
\text { half }\end{array}$ \\
\hline \multicolumn{5}{|c|}{ Initial state } \\
\hline \multirow{2}{*}{-} & $0-10$ & \multicolumn{3}{|c|}{1.1} \\
\hline & $10-20$ & \multicolumn{3}{|c|}{1.0} \\
\hline \multicolumn{5}{|c|}{ First rotation } \\
\hline \multirow{2}{*}{ P 18-20 } & $0-10$ & 1.2 & 1.3 & 1.4 \\
\hline & $10-20$ & 1.1 & 1.3 & 1.4 \\
\hline \multirow{2}{*}{ ML 18-20 } & $0-10$ & 1.5 & 1.6 & 1.8 \\
\hline & $10-20$ & 1.3 & 1.4 & 1.5 \\
\hline \multirow{2}{*}{ MD $\frac{10-12}{18-20}$} & $0-10$ & 1.4 & 1.6 & 1.6 \\
\hline & $10-20$ & 1.2 & 1.4 & 1.4 \\
\hline Min. sign. diff. ${ }_{05}, \%$ & \multicolumn{4}{|c|}{0.1} \\
\hline \multicolumn{5}{|c|}{ Друга ротація second rotation } \\
\hline \multirow{2}{*}{ P $18-20$} & $0-10$ & 1.1 & 1.2 & 1.3 \\
\hline & $10-20$ & 1.0 & 1.1 & 1.2 \\
\hline \multirow{2}{*}{ ML 18-20 } & $0-10$ & 1.3 & 1.5 & 1.6 \\
\hline & $10-20$ & 1.0 & 1.1 & 1.3 \\
\hline \multirow{2}{*}{$\operatorname{MD} \frac{10-12}{18-20}$} & $0-10$ & 1.2 & 1.5 & 1.7 \\
\hline & $10-20$ & 1.0 & 1.0 & 1.1 \\
\hline Min. sign. diff. $05, \%$ & \multicolumn{4}{|c|}{0.1} \\
\hline
\end{tabular}

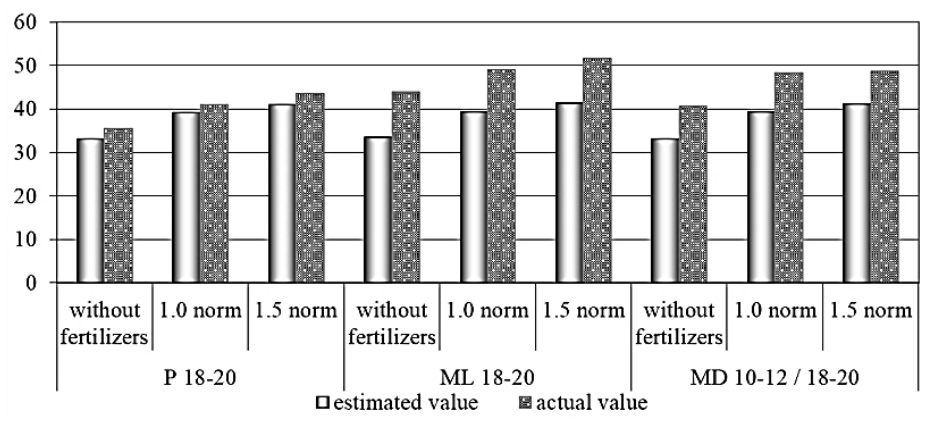

Fig. 2. Humus stocks in the soddy podzolic soil for the end of the first rotation of a crop rotation, $t /$ hectare

12 Кравчук М.М. Оптимізація режиму органічної речовини у легких за гранулометричним складом грунтах Полісся : автореф. дис. ... канд. с.-г. наук : 06.01 .03 «Агрогрунтознавство і агрофізика». Київ, 2005. 21 с. 
In the second rotation the general trends of dynamics of organic matter which took place in the first remained, but levels of accumulation of a humus in a layer of 0-20 cm significantly decreased: in comparison with an initial state on the fertilized backgrounds gains on condition of plowing were $10.3-19.8 \%$ on a moldboardless $-24.9-37.5 \%$, and in the conditions of soil-protective different depths tillage $-22.5-30.9 \%$. On option without fertilizers the difference was within an experience error ${ }^{13}$. Certainly, such losses of a humus during one rotation should be connected with dynamics of the most active part of organic matter, in particular, prehumic as specific humic connections are relatively thermodynamic steady chemicals. In this regard the specified levels of accumulation of a humus more reflect processes of transformation of a nonhumification part of soil organic matter.

\section{Way of definition of the detritus in lungs on particle size distribution soils}

Organic matter is the most contradictory substance in an ecosystem. The role it in the biosphere is difficult and many-sided, and contents is considered as a key indicator of soil fertility, assessment of stability, balance and power of ecosystems. In structure soil organic chemistry it is possible to allocate the following groups of substances:

- not decayed remains, including roots of vegetative plants and the remains of dead roots, organic fertilizers, seeds of weeds which are saved up for last years and others;

- detritus - the semi-decayed fossils which lost anatomic similarity to initial material, however do not form strong communications with a mineral part of the soil;

- humus - specific nitrogen-containing, high-molecular connections of the acid nature (humic acids, fulvic acids, gumin). Fulvic acids soluble in water, humic and, especially, gumina form a steady organo-mineral complex of the soil.

The first two groups of organic matter on ability to transformation is relatives and belong to labile forms of organic chemistry which term of full decomposition is measured in the days, months and years whereas stable humic connections - dozens, hundreds and thousands of years. Various stability of the specified groups of organic matter is connected

13 Кравчук М.М. Оптимізація режиму органічної речовини у легких за гранулометричним складом грунтах Полісся : автореф. дис. ... канд. с.-г. наук : 06.01.03 «Агрогрунтознавство і агрофізика». Київ, 2005. 21 с. 
with their chemical structure and communication with a mineral phase of the soil ${ }^{14}$.

In world practice the definition of a humus is carried out by methods of wet (by Tyurin, Walkley\&Black, Orlov-Grindel, Nikitin and others) and dry burning. However, these methods do not make a real picture of maintenance actually of the humus better, and allow to establish only a lump of humus as in an analytical hinge plate of the soil together with a humus it is burned and detritus that leads to overestimate of data ${ }^{15}$. At the same time variation of contents of the detritus by researchers is transferred to dynamics of a humus in connection with various agrotechnical measures whereas actually humic connections are more conservative substances and quantitatively change slow rates. Despite it, for assessment of the impact of agrotechnologies on soil organic matter it is recommended to use in addition the quantitative maintenance of its nonhumification part ${ }^{16,17}$.

It was established that the combination of granulometric and densimetric methods of fractionation allows to emit nonhumification organic matter in the fullest measure.

Definition of the detritus is carried out in two stages: field and laboratory $^{18}$.

The field stage of works provides sampling of the soil of the fixed volume and finishing them to an air-dry state. The laboratory stage consists of two consecutive blocks: preparatory and actually analytical definition of the detritus.

The preparatory block provides siftings of all material through a sieve with a diameter of openings of $1 \mathrm{~mm}$ that allows to prepare material for

14 Стрельченко В.П., Кравчук М.М. Вплив глейового процесу на дегуміфікацію дерново-підзолистих грунтів. Вісник аграрної науки. 2004. № 7. C. $18-20$.

${ }^{15}$ Ганжара Н.Ф., Борисов Б.А. Гумусообразование и агрономическая оценка органического вещества почв. Москва : Агроконсалт, 1997. 852 с.

16 Мукина Л.Р., Шпедт А.А. Содержание и запасы лабильного органического вещества в почвах агроценозов и залежей. Вестник Красноярского ГАУ. 2008. № 4. С. 37-41.

17 Борисов Б.А. Легкоразлагаемое органическое вещество целинных и пахотных почв зонального ряда европейской части России : автореф. дис. ... д. биол. н. : 03.00.27 «Почвоведение»; МСХА им. К.А. Тимирязева. Москва, $2008.40 \mathrm{c}$.

18 Кравчук М.М. Оптимізація режиму органічної речовини у легких за гранулометричним складом грунтах Полісся : автореф. дис. ... канд. с.-г. наук : 06.01.03 «Агрогрунтознавство і агрофізика». Київ, 2005. 21 с. 
the analysis on contents of the detritus and in parallel to define the maintenance of fraction of not decayed vegetable remains which includes live and dead roots, the remains of a ground litter, organic fertilizers, seeds of weeds, etc.

Analytical definition of the detritus is carried out by careful decantation by water from a fine earth part of a sample (material $<1.0 \mathrm{~mm}$ ) from a mineral part and specific organic chemistry with use of a sieve of $0.25 \mathrm{~mm}$. At the same time the high hydrophility (363\%) and swelling of the detritus promote its delay on a sieve whereas the high-disperse organo-mineral complex together with humic substances passes through it ${ }^{19}$.

\section{Nonhumification of organic substance of Polissia soils}

At assessment of the mode of organic matter in soils as a key indicator volume of intake of fossils and stocks of a humus are used, and processes of transformation of nonhumification organic matter, in particular the vegetable remains and the detritus, are practically not considered. At the same time, detritus is rather sensitive to influence of agrotechnical actions, on which dynamics it is possible to track orientation of processes of accumulation of a humus. In this regard we studied dynamics of stocks of the detritus in agrotechnologies on soddy podzolic and light gray forest soils.

It turned out that the soil-protective technology of cultivation of cultures on soddy podzolic soils based on tillage without an arable land turn is characterized by essential advantage on accumulation of nonhumification organic matter in comparison with technologies on the basis of plowing. This advantage is accurately shown even on backgrounds without fertilizers. So, in the conditions of prolonged use of soil-protective agrotechnologies against the background of where application of fertilizers was provided, in an arable layer stocks of the vegetable remains increased by 5.0 t/hectare or $66.9 \%$, and the detritus by $2.39 \mathrm{t} /$ hectare $(81.6 \%)$ in comparison with traditional agrotechnologies on the basis of plowing (fig. 3).

Use of fertilizers significantly enhances efficiency of both a usual way of tillage of the soil, and soil-protective, in particular, in the conditions of plowing gains of the vegetable remains and the detritus in an arable layer depending on the level of fertilizer were 34.0-78.1 and

19 Кравчук М.М. Оптимізація режиму органічної речовини у легких за гранулометричним складом грунтах Полісся : автореф. дис. ... канд. с.-г. наук : 06.01.03 «Агрогрунтознавство і агрофізика». Київ, 2005. 21 с. 
$52.6-77.8 \%$, and on soil-protective tillage $-18.0-123.5 \%$ and $22.7-103.4 \%$ respectively.

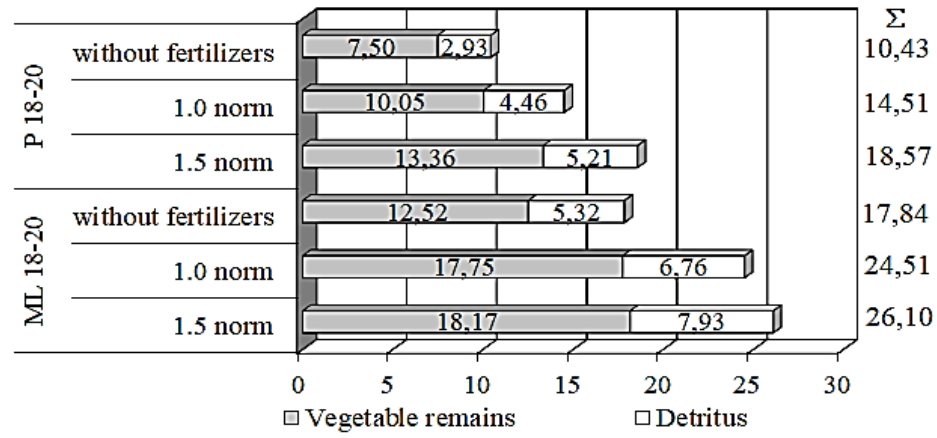

Fig. 3. Influence of agrotechnologies on the maintenance of the vegetable remains and the detritus in the soddy podzolic soil (a winter rye, a layer of $0-20 \mathrm{~cm}$ ), $t /$ hectare $^{20}$

Accounting of nonhumificated organic matter at cultivation of a winter rye in experience found also heterogeneity of its distribution in a profile of an arable layer (tab. 4). It is shown at all ways of tillage of the soil and the systems of fertilizer, however tillage without turnover of layer is characterized by more accurate differentiation that corresponds to features of manifestation of soil formation of soddy type at which accumulative processes are weakened with a depth. So, at the time of collecting a winter rye on soddy podzolic soils in the conditions of prolonged use of soilprotective agrotechnologies the coefficient of heterogeneity of maintenance of the vegetable remains made 3.06-3.31, the detritus - 2.28-3.16. At the same time in the system of plowing the vertical heterogeneity of stocks of a nonhumificated organic matter in an arable layer is expressed less that is result of systematic mechanical intervention.

In researches on light gray forest soils the positive role of organic fertilizers on accumulation of the vegetable remains and the detritus is revealed and it is shown that over time their action weakens (fig. 4). Thus, stocks of the vegetable remains and the detritus after cropping potatoes (direct effect of organic fertilizers) were big in comparison with the levels reached after cleaning of a winter rye (an after-effect of the

${ }^{20}$ Кравчук М.М. Оптимізація режиму органічної речовини у легких за гранулометричним складом грунтах Полісся : автореф. дис. ... канд. с.-г. наук : 06.01.03 «Агрогрунтознавство і агрофізика». Київ, 2005. 21 с. 
second year) for 62.8 and $40.4 \%$ respectively. On option where fertilizers were not applied, potato conceded in accumulation of stocks of the vegetable remains and the detritus of field peas+oat mix for 55 and $19.9 \%$ and a winter rye for $16.5 \%$ and $5.5 \%$ respectively.

Table 4

Influence of agrotechnologies on differentiation of an arable layer of the soddy podzolic soil for the content of nonhumificated organic matter, $n=25, t_{05}=2.01$ (RF “GROZINSKE", winter rye) ${ }^{21}$

\begin{tabular}{|c|c|c|c|c|c|}
\hline \multirow{2}{*}{ System of tillage } & \multirow{2}{*}{ Fertilizer level } & \multicolumn{2}{|c|}{ Vegetable remains } & \multicolumn{2}{|c|}{ Detritus } \\
\cline { 3 - 6 } & Without fertilizers & $\boldsymbol{C}_{\boldsymbol{h}}$ & $\boldsymbol{t}_{\boldsymbol{f}}$ & $\boldsymbol{C}_{\boldsymbol{h}}$ & $\boldsymbol{t}_{\boldsymbol{f}}$ \\
\hline \multirow{4}{*}{ P 18-20 } & One norm & 1,40 & 5,32 & 1,05 & 0,68 \\
\cline { 2 - 6 } & $\begin{array}{c}\text { One and a half } \\
\text { norms }\end{array}$ & 1,17 & 2,42 & 1,13 & 1,52 \\
\hline \multirow{3}{*}{ ML 18-20 } & Without fertilizers & 3,31 & 19,65 & 3,16 & 20,9 \\
\cline { 2 - 6 } & One norm & 3,06 & 13,98 & 2,44 & 14,25 \\
\cline { 2 - 6 } & $\begin{array}{c}\text { One and a half } \\
\text { norms }\end{array}$ & 3,06 & 15,28 & 2,28 & 12,06 \\
\hline
\end{tabular}

Notes: $C_{h}$ - heterogeneity coefficient; $t_{f}$ - is criterion of importance of a difference of maintenance of a nonhumification of organic matter in a profile of an arable layer of earth $(0-10$ and $10-20 \mathrm{~cm})$.

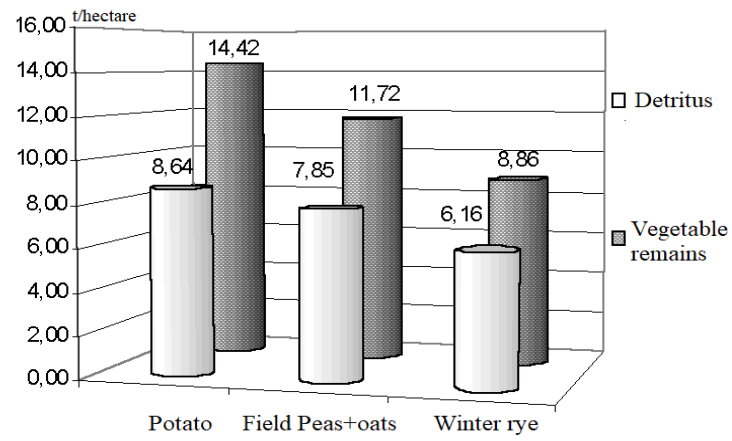

Fig. 4. Stocks of the vegetable remains and the detritus in the light gray forest soil under the cultures of a crop rotation on the organo-mineral system of fertilizer (a layer of $0-20 \mathrm{~cm}$ )

21 Кравчук М.М. Оптимізація режиму органічної речовини у легких за гранулометричним складом грунтах Полісся : автореф. дис. ... канд. с.-г. наук : 06.01.03 «Агрогрунтознавство і агрофізика». Київ, 2005. 21 с. 
At the end we carried out the comparative analysis whenever possible of reproduction of organic matter in soddy podzolic and light gray forest soils. Stocks of nonhumificated organic matter chemistry on these objects which are recorded in final fields of rotation of crop rotations of both hospitals after cultivation of a winter rye were for this purpose analyzed. The conducted researches showed that overall effectiveness of soil-protective technologies essential and gives the chance to provide significant gains of a nonhumificated organic matter on all backgrounds of research cultures.

In spite of the fact that light gray forest soils have the best prerequisites for accumulation of organic matter, however, levels of accumulation of the vegetable remains and the detritus in soddy podzolic were much higher. Thus, the mass of the vegetable remains and the detritus in an arable layer on agrobackgrounds where long time soilprotective technologies without application of fertilizers were applied, was $5.0 \mathrm{t} /$ hectare more $(66.8 \%)$ and $0.84 \mathrm{t} /$ hectare $(18.6 \%)$ respectively (tab. 5). It is connected with optimization of the mode of organic matter and establishment of an equilibrium condition of its stocks under the influence of agrotechnical actions. The special value at the same time belongs to a crop rotation, in particular, of duration of its functioning. On option with application of fertilizers lead of stabilized agrobackgrounds (RF "GROZINSKE"') was increased. For example, accumulation levels plant residues were 9.31 t/hectare higher than the remains in soddy podzolic soils $(105.1 \%)$, and the detritus - on $1.77 \mathrm{t} /$ hectare $(28.7 \%)$ in comparison with light gray forest soils ${ }^{22}$.

In general, it should be noted that even on destabilized backgrounds of use of organic fertilizers allows to influence significantly accumulation of the vegetable remains and the detritus and to provide high levels of their reproduction for short term. However, such advantages in accumulation are temporary and are possible only for mobilization of resource factors as the nonhumificated organic matter represents quite dynamic phase of the soil.

Results of researches show that the soil-protective agrotechnology is crucial in optimization of the mode of organic matter of the soil, providing stabilization of agroecosystems and the prolonged action of resource factors for accumulation of the vegetable remains and the detritus.

22 Кравчук М.М. Оптимізація режиму органічної речовини у легких за гранулометричним складом грунтах Полісся : автореф. дис. ... канд. с.-г. наук : 06.01.03 «Агрогрунтознавство і агрофізика». Київ, 2005. 21 с. 
Table 5

Reserves of nonhumification organic matter in soddy podzolic and light gray forest soils (a winter rye, a layer of $0-20 \mathrm{~cm}, \mathbf{n}=50)^{23}$

\begin{tabular}{|c|c|c|c|c|}
\hline \multirow[b]{2}{*}{ Soil } & \multirow[b]{2}{*}{ Background } & \multicolumn{3}{|c|}{ Stocks, t/hectare } \\
\hline & & total & $\begin{array}{c}\text { plant } \\
\text { residues }\end{array}$ & detritus \\
\hline \multirow{2}{*}{$\begin{array}{l}\text { Soddy podzolic } \\
\text { clay-sand }\end{array}$} & $\begin{array}{l}\text { Without } \\
\text { fertilizers }\end{array}$ & 17.84 & 12.52 & 5.32 \\
\hline & Fertilizers $^{*}$ & 26.1 & 18.17 & 7.93 \\
\hline \multirow{2}{*}{$\begin{array}{l}\text { Light gray forest } \\
\text { sandy }\end{array}$} & $\begin{array}{l}\text { Without } \\
\text { fertilizers }\end{array}$ & 11.99 & 7.51 & 4.48 \\
\hline & Fertilizers $^{* * 3}$ & 15.02 & 8.86 & 6.16 \\
\hline \multirow{2}{*}{ Deviation $^{* * *}$} & $\begin{array}{c}\text { Without } \\
\text { fertilizers }\end{array}$ & $\begin{array}{l}5.85 \\
48.8\end{array}$ & $\begin{array}{l}5.01 \\
66.7 \\
\end{array}$ & $\begin{array}{l}0.84 \\
18.8 \\
\end{array}$ \\
\hline & Fertilizers & $\begin{array}{c}11.08 \\
73.8 \\
\end{array}$ & $\begin{array}{c}9.31 \\
105.1 \\
\end{array}$ & $\begin{array}{l}1.77 \\
28.7 \\
\end{array}$ \\
\hline \multirow{2}{*}{$\begin{array}{l}\text { Min. sign. diff. } 05, \\
\text { t/hectare }\end{array}$} & $\begin{array}{c}\text { Without } \\
\text { fertilizers }\end{array}$ & - & 2.34 & 0.82 \\
\hline & Fertilizers & - & 3.06 & 1.12 \\
\hline
\end{tabular}
denominator - in \%.

\section{Agronomy and Energy efficiency of soil-protective technologies of crops cultivation}

The soil-protective system of tillage in combination with fertilizers on light gray forest soils promoted increase in productivity of cultures of a crop rotation. Thus, application of a mineral system of fertilizer in a crop rotation provided gains of productivity of potatoes on $6.41 \mathrm{t} /$ hectare $(82.5 \%)$, Peas Field + oats (after-effect) - on 0.65 t/hectare $(32.4 \%)$, a winter rye - on $1.30 \mathrm{t} /$ hectare $(49.0 \%)$. Organo-mineral system of fertilizer promoted increase in productivity of potatoes on $7.83 \mathrm{t} / \mathrm{hectare}$ $(100.8 \%)$, Peas Field + oats (after-effect) - on 0.53 t/hectare $(26.3 \%)$, a winter rye (an after-effect of the second year of organic fertilizers, direct action mineral) - on $1.45 \mathrm{t} /$ hectare $(54.6 \%)$.

The power analysis of cultivation of cultures of a crop rotation showed that soil-protective technologies provided positive balance of energy. So, in process of production of potatoes depending on the system of fertilizer energy of anthropogenic origin in the volume of 17.7-48.4

23 Кравчук М.М. Оптимізація режиму органічної речовини у легких за гранулометричним складом грунтах Полісся : автореф. дис. ... канд. с.-г. наук : 06.01.03 «Агрогрунтознавство і агрофізика». Київ, 2005. 21 с. 
thousand $\mathrm{MJ} / \mathrm{hectare}$ of an arable land was used that allowed to receive 68.8-138.3 thousand $\mathrm{MJ} /$ hectare of energy of the main and collateral products. Higher power efficiency characterized cultivation of Peas Field + oats where 9.1-9.8 thousand $\mathrm{MJ} /$ hectare of anthropogenic energy (agrochemical providing is absent) were received by 75.4-99.8 thousand $\mathrm{MJ} / \mathrm{h}$ ectare of the main and valuable collateral products in the economic relation. Still the best results on an energy output were reached in the conditions of cultivation of a winter rye. Thus, against the background of soil-protective tillage without application of fertilizers 124.3 thousand $\mathrm{MJ} / \mathrm{hectare}$ of energy, and on option of an organo-mineral system of fertilizer in a crop rotation -191.8 thousand $\mathrm{MJ} / \mathrm{h}$ ectare of the main and collateral products were received ${ }^{24}$.

Considering that dynamics of productivity and stable functioning of an agroecosystem are in close interrelation, internal energy of the soil can be universal criterion for evaluation of its state. Power capacity of the soil substantially is defined by dynamics of maintenance of organic matter as the last is high-power-intensive material ${ }^{25}$. So, on the basis of direct definition it is established that the power consumption of the vegetable remains was up to standard 5392.5, the detritus $-4349.2 \mathrm{MJ} / \mathrm{t}$, and to soils this indicator was $387.2-314.5 \mathrm{MJ} / \mathrm{t}^{26}$.

Calculation showed that use of soil-protective technologies of cultivation of crops provided increase in power consumption of the soil in comparison with traditional technologies on the basis of plowing. Thus, after cultivation of a winter rye without application of fertilizers gain of energy was $37465 \mathrm{MJ} /$ hectare (a layer of $0-20 \mathrm{~cm}$, RF "GROZINSKE"). Use of fertilizers in technologies caused increase in power consumption of soil-protective agrobackgrounds at 51438.5 $\mathrm{MJ} /$ hectare against backgrounds where plowing was carried out.

\section{CONCLUSIONS}

It is experimentally installed a versatile role of agrotechnologies and gley process in the dynamic of organic matter of zonal soils of Polissia

24 Кравчук М.М. Оптимізація режиму органічної речовини у легких за гранулометричним складом грунтах Полісся : автореф. дис. ... канд. с.-г. наук : 06.01.03 «Агрогрунтознавство і агрофізика». Київ, 2005. 21 с.

${ }^{25}$ Ганжара Н.Ф., Борисов Б.А. Гумусообразование и агрономическая оценка органического вещества почв. Москва: Агроконсалт, 1997. 852 с.

26 Кравчук М.М. Оптимізація режиму органічної речовини у легких за гранулометричним складом грунтах Полісся : автореф. дис. ... канд. с.-г. наук : 06.01.03 «Агрогрунтознавство і агрофізика». Київ, 2005. 21 с. 
and possibilities of influence on its structure for ensuring stability of agroecosystems are shown. At the same time, it is possible to give the following conclusions.

1. Wide circulation of processes of a dehumification of zonal soils of Polissia is a consequence of violation of balance in an agroecosystem through low levels of intake of organic substrate, application of poor systems of tillage and fertilizer proved from ecological positions and also non-compliance with crop rotations.

2. Productivity of a crop rotation (Psiv) substantially correlates with stocks of a humus $(G)$. In experimental conditions on soddy podzolic clay-sand soils such dependence was described by the general equation: Psiv $=0,92363 G-3,445(r=0,85)$.

3. Soil-protective agrotechnologies which included tillage without turnover of layer and application of fertilizers had the greatest positive influence on accumulation of a humus. So, for the first rotation of a crop rotation against the background of plowing of rather initial condition of application of an organo-mineral system of fertilizer provided increase in stocks of a humus by $22.9-30.5 \%$, and at moldboardless tillage - for 31.4-54.8\%, against the background of soil-protective allopelagic - for 21.4-45.7\%. Advantage in efficiency of soil-protective tillage on accumulation of organic matter is established also on options without fertilizers.

4. Correction of a system of fertilizer of cultures in the second rotation of a crop rotation towards reduction of norms caused sharp decrease in volumes of accumulation of a humus on all options of experience. Thus, in the conditions of plowing depending on fertilizer levels gains of maintenance of a humus in comparison with an initial state were only in limits of 10.3-19.8\%, on soil-protective moldboardless tillage $-24.9-37.5 \%$, and in the conditions of soil-protective different depths technology $-22.5-30.9 \%$. Such intensive dehumification of the soil it is for a short time caused by rather high dynamite of detritus fraction of organic matter which is considered at analytical definition of a humus.

5. It is proved that along with agrotechnical factors (deep plowing, insufficient intake of organic substrate) the significant effect on a dehumification of the soil has gley process. It is experimentally established that in the course of a gley process of the primary schedule test the vegetable remains and detritus, actually humic substances as steady chemical compounds at the same time quantitatively change less. In experience the term of full decomposition of nonhumificated organic 
matter (also detritus the vegetable remains) did not exceed 4 years. After a detritus mineralization the maintenance of a humus in the soil for the 4th year of an experiment made $0.9 \%$, and on the 17 th $-0.67 \%$.

6. Use of organic fertilizers in an agroecosystem allows to reproduce quickly stocks of nonhumificated organic matter to certain equilibrium values which can be contained only during action of mobilization of resource factors as and detritus the vegetable remains represent quite dynamic phase of the soil. So, in experimental conditions in a short crop rotation on light gray forest soils when using in the system of fertilizer of potatoes of manure, straw, green manure $(56.5$ t/hectare in terms of manure) in the first year of action the maintenance of the vegetable remains and the detritus in an arable layer made respectively 14.4 and $8.6 \mathrm{t} / \mathrm{hectare}$, in an after-effect after culture Peas Field + oat (mix) 11.7 and $7.8 \mathrm{t} / \mathrm{hectare}$, and after a winter rye -8.9 and $6.2 \mathrm{t} / \mathrm{hectare}$.

7. Comparative analysis concerning opportunities of reproduction of organic matter in soddy podzolic and light gray forest soils showed that long functioning of agroecosystems (18 years) provided advantage in accumulation of the vegetable remains and the detritus in soddy podzolic soils in spite of the fact that light-gray forest soils are characterized by the best genetic prerequisites for accumulation of organic matter. The difference in accumulation of nonhumificated organic matter in an arable layer between the specified types of soils made 5.8 (without fertilizers) and $11.1 \mathrm{t} /$ hectare (on fertilized a background).

9. In ensuring optimization of structure of organic matter the soilprotective agrotechnologies based on tillage of the soil without turnover of layer are crucial. Thus, in the conditions of prolonged use of the specified technologies without application of fertilizers the level of accumulation of the vegetable remains in an arable layer were higher in comparison with the corresponding backgrounds of plowing on $5.0 \mathrm{t} /$ hectare, and the detritus - on $2.4 \mathrm{t} /$ hectare. At the background of fertilizers the efficiency of technologies significantly increased.

\section{SUMMARY}

The analysis of influence of agrotechnologies on dynamics of maintenance of a humus is provided in the soddy podzolic soil of laboratory of agroecology of Institute of agriculture of Polissia by NAAS. Results of a research on accumulation of the detritus under the influence of various systems of fertilizer which were carried out on light gray forest soil in stationary experience of the Polissia National University are also presented. It is established that use of soil-protective 
agrotechnologies promotes ensuring optimization of the mode of organic matter of zonal soils of Polissia due to reproduction of its nonhumification part. In a short crop rotation Field Peas+oats mix) - a winter rye - potatoes are necessary elements of technologies tillage of the soil without turnover of layer (moldboardless tillage on $18-20 \mathrm{~cm}$ under summer cultures and disk tillage on 10-12 cm under winter) and also the organo-mineral system of fertilizer which provides introduction under a winter rye of $3 \mathrm{t} /$ hectare of straw $+\mathrm{N}_{60} \mathrm{P}_{45} \mathrm{~K}_{45}$ (including $\mathrm{N}_{30}$ is a compensation dose), under potatoes of $30 \mathrm{t} / \mathrm{hectare}$ of manure + $3 \mathrm{t} /$ hectare of straw $+20 \mathrm{t} /$ hectare of green manure $+\mathrm{N}_{75} \mathrm{P}_{50} \mathrm{~K}_{60}$ (including $\mathrm{N}_{30}$ is a compensation dose) that on hectare of a crop rotation makes $22 \mathrm{t}$ of organic fertilizers (in terms of manure) $+\mathrm{N}_{45} \mathrm{P}_{32} \mathrm{~K}_{35}$. Content of nonhumificated organic matter (also detritus and vegetable remains) is recommended to be entered into indicators which characterize an agrophysical condition and level of fertility of soils.

\section{References}

1. Кравчук М.М., Мартенюк Г.М., Кравчук Т.В. Вплив агротехнологій на запаси детриту в ясно-сірих лісових грунтах Полісся. Новітні системи землеробства та иляхи підвищення еколого-біологічної ефективності використання земель в сучасному агрокомплексі : матеріали Міжнар. науково-практ. конф. Дніпро : ДДАЕУ, 2017. С. 108-110.

2. Ковда В. А. Биохимия почвенного покрова. Москва : Наука, 1985. $263 \mathrm{c}$.

3. Стрельченко В.П., Кравчук М.М. Вплив грунтозахисних агротехнологій на динаміку органічної речовини дерновопідзолистих грунтів Полісся. Науковий вісник НАУ. 2005. Вип. 81. C. 29-34.

4. Кравчук М.М., Кропивницький Р.Б., Кравчук Т.В. Негуміфікована органічна речовина грунту як фактор регулювання твердості світло-сірих лісових грунтів Полісся. Вісник ЖНАЕУ. 2015. № 2 (50), т. 1. С. 10-15.

5. Ганжара Н.Ф., Борисов Б.А. Гумусообразование и агрономическая оценка органического вещества почв. Москва : Агроконсалт, 1997. $852 \mathrm{c.}$

6. Борисов Б.А. Легкоразлагаемое органическое вещество целинных и пахотных почв зонального ряда европейской части России : автореф. дис. ... д. биол. н. : 03.00.27. «Почвоведение»; МСХА им. К.А. Тимирязева. Москва, 2008. 40 с. 
7. Ганжара Н.Ф. Почвоведение. Москва : Агроконсалт, 2001. $392 \mathrm{c}$.

8. Мукина Л.Р., Шпедт А.А. Содержание и запасы лабильного органического вещества в почвах агроценозов и залежей. Вестник Красноярского ГАУ. 2008. № 4. С. 37-41.

9. Кравчук М.М. Оптимізація режиму органічної речовини у легких за гранулометричним складом грунтах Полісся : автореф. дис. ... канд. с.-г. наук : 06.01 .03 «Агрогрунтознавство i агрофізика». Київ, 2005. 21 с.

10. Стрельченко В.П., Кравчук М.М. Вплив глейового процесу на дегуміфікацію дерново-підзолистих грунтів. Вісник аграрної науки. 2004. № 7. C. 18-20.

Information about the authors: Kravchuk Mykola Mykolaiovych, Candidate of Agricultural Sciences, Associate Professor, Associate Professor at the Department of Soil Science and Agriculture Polissia National University 7, Staryi bloulevard, Zhytomyr, 10008, Ukraine

Kropyvnytskyi Ruslan Bronislavovych, Candidate of Agricultural Sciences, Associate Professor, Associate Professor at the Department of Soil Science and Agriculture Polissia National University 7, Staryi boulevard, Zhytomyr, 10008, Ukraine 